\title{
KETERBACAAN TEKS DALAM BUKU SISWA KELAS VI SEKOLAH DASAR
}

\author{
${ }^{1}$ Muhammad Choirul Imam, ${ }^{2}$ Kisyani Laksono, ${ }^{3}$ Suhartono \\ ${ }^{1}$ Mahasiswa Program Pascasarjana, Prodi Pendidikan Dasar, Universitas Negeri Surabaya, \\ ${ }^{2 \& 3}$ Dosen Pascasarjana, Prodi Pendidikan Dasar, Universitas Negeri Surabaya \\ e-mail: imam30069017@gmail.com
}

Received : November 2017

Reviewed: Desember 2017

Accepted : Januari 2018

Published : Januari 2018
ABSTRACT

This research purposed to describe the readability tex in the six grade book. This purpose atributed with three manners for analyzing readability levels, tes of question and answer, readability formula, and cloze tes. This research diversified quantitative-qualitative by descriptive method. This research subject was twenty seven text from nine theme, also student in Lamongan The Elementary School of Paciran 1. To collect data, used documentation technique (Fry Graph), also word association test, and cloze test. The data of Fry Graph, word association test, and cloze tes taken from the described score taken from describe the parts. The result of this research is first, the readability text based on early knowledge of readers about topics were difficult because of the percentage result from the test of word association were $29 \%$. Second, the readability tekt based on the readability levels based on readability formula(Fry Graph) is 7, 8, dan 9 also very close long word area. Third, the readability text based on the vocabularies control which was influenced by the language knowledge student was difficult because of the percentage result from Cloze test was 10\%. Therefore, teks in The Six Grade Book was difficulted to readable and comprehended student class VI because the quality text based on long-short word, knowledge readers (early and vocabularies control) and Cloze test was difficult.

Keywords: Readability Teks, Word Association Tes, Fry Graph, Cloze Tes.

\section{ABSTRAK}

Penelitian ini bertujuan mendeskripsikan tentang keterbacaan teks yang termuat dalam buku siswa kelas VI. Tujuan tersebut juga terkait dengan tiga cara untuk menganalisis tingkat keterbacaan, yakni tes tanya jawab, formula keterbacaan dan tes Cloze. Penelitian ini berjenis kualitatif-kuantitatif dengan metode deskriptif. Subjek penelitian ini adalah dua puluh tujuh teks dalam sembilan tema, serta siswa di SD Negeri Paciran I Lamongan. Untuk mengumpulkan data, digunakan teknik dokumentasi (Grafik Fry) serta tes asosiasi kata dan tes Cloze. Data dari Grafik Fry, tes asosiasi kata, dan tes Cloze berupa skor yang dideskripsikan serta data dari analisis berupa deskripsi. Hasil penelitian ini pertama, tingkat keterbacaan teks berdasarkan pengetahuan awal pembaca tentang topik adalah rendah karena hasil presentasi tes asosiasi kata 29\%. Kedua, tingkat keterbacaan teks berdasarkan formula keterbacaan (Grafik Fry) adalah 7, 8, dan 9 serta mendekati daerah long word. Ketiga, tingkat keterbacaan berdasarkan tes Cloze yang dipengaruhi oleh pengetahuan kebahasaan siswa itu sulit karena hasil persentase tes Cloze $10 \%$. Dengan demikian, teks dalam buku teks kelas VI sulit dibaca dan dipahami siswa kelas VI karena kualitas teks berdasarkan pengetahuan siswa, panjang-pendek, dan tes Cloze tergolong sulit.

Kata Kunci: Tingkat Keterbacaan Teks, Asosiasi Kata, Grafik Fry, Tes Cloze 


\section{PENDAHULUAN}

Salah satu faktor penentu keberhasilan pembelajaran di sekolah dasar adalah buku teks atau buku pelajaran yang digunakan sebagai penunjang pembelajaran. Buku teks adalah buku yang dijadikan pegangan siswa sebagai sumber belajar. Buku teks yang dijadikan pegangan oleh siswa dalam pembelajaran di sekolah dasar harus sesuai dengan kurikulum pendidikan nasional dan berfungsi mendukung terbentuknya kompetensi lulusan siswa. Buku teks adalah buku yang dirancang untuk penggunaan di kelas. Buku yang ditulis, disusun, dan disiapkan dengan cermat oleh pakar atau ahli dalam bidang itu dan diperlengkapi dengan sarana-sarana pengajaran yang sesuai dan serasi Bacon (Tarigan dan Tarigan, 2009:12).

Sejalan dengan hal tersebut, maka penting untuk dilakukan studi evaluatif tingkat keterbacaan dalam buku teks tematik siswa kelas VI di SDN Paciran 1 Lamongan dengan tes keterbacaan. Peneliti melakukan penelitian tingkat kemampuan keterbacaan di SDN Paciran 1 di kelas VI, karena guru yang mata pelajaran bahasa Indonesia belum mengevaluasi tingkat keterbacaan bahan ajar yang digunakan. Di samping itu, dalam pemilihan bahan ajar guru hanya memperhatikan kerelevasiannya terhadap kurikulum maupun silabus yang ada tanpa mengevaluasi tingkat keterbacaannya.

Penelitian ini berfokus pada kriteria tersebut karena buku teks memuat materi-materi yang disajikan secara komunikatif. Dengan demikian, aspek-aspek linguistik penting untuk diperhatikan dalam menyusun buku teks karena secara tidak langsung mampu memengaruhi kemampuan materi yang disajikan dalam buku teks untuk terbaca pesannya oleh pembaca. Padahal, buku teks diketahui banyak menyajikan materi dalam bentuk bacaan. Kemampuan terbacanya bacaan oleh pembacanya merupakan definisi dari keterbacaan. Mucholish, dkk. (1992:167) berpendapat bahwa keterbacaan merupakan pengukuran tingkat kesulitan sebuah buku atau wacana secara objektif.

Keterbacaan antara lain bergantung pada kosakata dan bangun kalimat yang dipilih oleh pengarang untuk tulisannya. Tulisan yang banyak mengandung kata yang tidak umum lebih sulit untuk dipahami daripada yang menggunakan kosakata sehari-hari, yang sudah dikenal oleh pembaca pada umumnya (Sakri, 1994:165). Sehingga hal itu berpengaruh pada tingkat pemahaman siswa SD, serta pendidikan belum maksimal di tingkat sekolah dasar.

Pendidikan merupakan unsur utama dalam pengembangan manusia Indonesia seutuhnya. Pengelolaan pendidikan harus berorientasi bagaimana menciptakan perubahan yang lebih baik. Oleh karena itu, pendidikan perlu diselenggarakan secara optimal supaya menghasilkan lulusan-lulusan yang berkualitas yang memiliki kompetensi sikap, keterampilan, dan pengetahuan sesuai dtandar nasional yang disepakati (Fadillah, 2014:17).

Sebagaimana yang telah disebutkan dalam Undang-undang Sistem Pendidikan Nasional Nomor 20 tahun 2003 bahwa. "Tujuan pendidikan nasional adalah untuk mengembangkan potensi peserta didik agar menjadi manusia yang beriman dan bertaqwa kepada Tuhan Yang Maha Esa, berakhlak mulia, sehat, berilmu, cakap, kreatif, mandiei dan menjadi warga Negara yang demokratis serta bertanggung jawab”.

Tujuan pendidikan tersebut, tidak terlepas dari kurikulum pendidikan. Kebijakan Peraturan Pemerintah No. 32 Tahun 2013 menyatakan bahwa kurikulum adalah "seperangkat rencana dan pengaturan mengenai isi dan babahn pelajaran serta cara yang digunakan sebagai pedoman penyelenggaraan kegiatan belajar mengajar". Kurikulum merupakan sebuah wadah yang akan menentukan arah pendidikan. Tanpa adanya kurikulum mustahil pendidikan akan berjalan dengan baik sesuai yang diharapkan.

Dalam jenjang pendidikan Sekolah Dasar di Indonesia digunakan 2 kurikulum, yaitu kurikulum KTSP dan kurikulum 2013. Kurikulum KTSP adalah kurikulum operasional yang disusun dan dilaksanakan oleh masingmasing satuan pendidikan (Mulyasa, 2012:20). Sedangkan, kurikulum 2013 adalah sebuah kurikulum yang dikembangkan untuk meningkatkan dan menyeimbangkan kemampuan soft skill dan hard skill yang berupa keterampilan, sikap, dan pengetahuan (Fadillah,2014:16). Pelaksanaan kurikulum 2013 pada jenjang Sekolah dasar dilaksanakan melalui pembelajaran dengan pendekatan tematik dan telah diterapkan pada kelas I, II, III, IV, V, dan VI. Sedangkan pada kelas III dan VI masih bisa dikatakan baru dalam menerapkan kurikulum 2013.

Buku tematik merupakan buku teks pembelajaran terpadu yang menggunakan tema untuk mengaitkan beberapa mata pelajaran sehingga dapat memberikan pengalaman bermakna kepada peserta didik. Sesuai dengan tahapan perkembangan anak, karakteristik cara anak belajar, konsep belajar dan pembelajaran bermakna, maka kegiatan pembelajaran bagi anak SD sebaiknya diilakukan dengan pembelajaran tematik. pembelajaran tematik adalah pembelajaran terpadu tepadu yang menggunakan tema untuk mengaitkan beberapa mata pelajaran sehingga dapat memberikan pengalaman bermakna kepada siswa. Tema adalah pokok pikiran atau gagasan pokok yang menjadi pokok pembicaraan. 
Buku siswa yang disediakan oleh pemerintah dalam kurikulum 2013 ini menjabarkan usaha minimal yang harus dilakukan peserta didik untuk mencapai kompetensi yang diharapkan. Sedangkan dalam proses belajar, peserta didik dipacu untuk mencari dari sumber belajar lain yang tersedia dan terbentang luas di sekitarnya. Oleh karena itu peran guru menjadi sangat penting dalam meningkatkan dan menyesuaikan daya serap peserta didik dengan ketersedian kegiatan pada buku tersebut. Guru diharapkan dapat memperkayanya dengan kreasi dalam bentuk kegiatan-kegiatan lain yang sesuai dan relevan yang bersumber dari lingkungan sosial dan alam daerah masingmasing..

Keterbacaan buku teks di sekolah dasar diestimasikan rendah. Keterbacaan buku teks tematik di sekolah dasar pada umumnya terlampau sulit sehingga hanya sebagian kecil siswa sekolah dasar yang mampu memahami isinya. Hal itu terjadi karena penyusunan buku ajar itu tidak memperhitungkan tingkat keterbacaannya (Harjasujana dan Misdan dalam Dinar, 2011). Kecurigaan terhadap rendahnya keterbacaan buku teks di sekolah dasar juga berdasarkan informasi awal yang didapatkan. Berdasarkan informasi awal tersebut, diketahui beberapa siswa sekolah dasar masih kesulitan menangkap pesan (isi) yang terdapat dalam wacana-wacana yang disajikan dalam buku teks. Keadaan tersebut dikhawatirkan akan mengakibatkan siswa tidak memahami materi-materi yang terdapat di dalam buku teks. Hal ini yang mendasari pentingnya dilakukan kajian tentang keterbacaan buku teks di sekolah dasar sehingga dapat diketahui apakah bacaan yang disajikan dalam buku teks sudah sesuai dengan tingkat perkembangan siswa.

Masalah keterbacaan dalam pengelolaan pengajaran membaca oleh sebagian besar guru Bahasa Indonesia belum mendapat perhatian. Sebagian besar guru Bahasa Indonesia tidak tahu alat ukur untuk menentukan tingkat keterbacaan teks. Ini berarti, sebagian besar guru Bahasa Indonesia belum memiliki kemampuan untuk mengukur tingkat keterbacaan materi bacaan yang dijadikan sebagai bahan ajar. Akibatnya, dapat diduga ada kesenjangan antara materi bacaan yang disajikan dengan tingkat pemahaman pembaca. Kesenjangan ini kemungkinan dapat mengurangi minat dan motivasi membaca siswa.

Keterbacaan berkaitan dengan keseluruhan unsur yang ada dalam teks atau materi bacaan. Menurut Gilliland (1972) ada lima cara untuk menentukan keterbacaan teks, yaitu penilaian subjektif para ahli, metode tanya jawab, formula keterbacaan, carta, dan tes cloze. Sehubungan dengan studi ini, maka yang dikaji menentukan keterbacaan teks adalah dengan formula keterbacaan.
Formula-formula keterbacaan yang dimaksud merupakan rumus-rumus yang menghasilkan angka sebagai indeks keterbacaan (Nuttall, 1985; Sitepu, 2010).

Menurut Chall (Zakulak dan Samuels, 1988:2), studi kontrol kosakata terkait dengan kosakata yang efektif untuk belajar membaca dari buku teks membaca. Mereka mempelajari "kata baru" di beberapa buku, berkali-kali mereka mengulangi, dan mereka kesulitan. Selain itu, study pengukuran keterbacaan berasal dari keterkaitan dalam pemahaman kesulitan dari konten wilayah buku teks.

Formula keterbacaan ada yang dikembangkan berbasis bahasa Inggris dan ada yang berbasis bahasa Indonesia. Yang berbasis bahasa Inggris seperti formula Flesch, Fog Index, SMOG, dan Grafik Fry, sedangkan yang berbasis bahasa Indonesia adalah formula BI. Sebagian besar pakar seperti Hartley, Trucman, dan Burnhill yang dikutip Ginting (1990) setuju bahwa semua formula keterbacaan yang dikembangkan dapat meramalkan apakah sebuah materi bacaan akan lebih sulit atau lebih mudah dipahami pembaca bila dibandingkan dengan materi bacaan yang lain. Bahkan, Fry lebih tegas menyatakan bahwa formula-formula keterbacaan tersebut dapat meramalkan membaca pemahaman sebanding dengan ramalan tes membaca dan tes IQ.

Indeks keterbacaan itu mempunyai hubungan yang signifikan dengan hasil membaca pemahaman sehingga formula keterbacaan tersebut dapat dipakai untuk memprediksi tingkat kesu-karan atau tingkat kemudahan bisa dipahaminya materi bacaan oleh pembaca. Prediksi tersebut dapat dijadikan pegangan untuk menentukan tingkat pembaca. Artinya, apakah teks itu sesuai dengan siswa tingkat SD, SMP, SMA atau mahasiswa. Selain itu, prediksi itu dapat juga dimanfaatkan untuk menentukan atau memilih materi bacaan yang sesuai dengan kemampuan pema-haman pembaca tingkat tertentu. Jika demikian halnya, maka perlu diketahui apakah tiap formula keterbacaan itu cermat menentukan tingkat keterbacaan sebuah teks sehingga teks tersebut efektif digunakan dalam proses pembelajaran membaca.

Berdasarkan uraian tersebut, maka dapat dinyatakan bahwa pelaksanaan pembelajaran di Sekolah Dasar harus berkembang, memerlukan wawasan dan sumber belajar yang sesuai dengan tingkat kelas siswa tersebut, melainkan sesuai dengan konteks. Sehingga peserta didik mampu memahami dan meningkatkan keterampilan, baik keterampilan mengamati, menganalisis, menanya, mendemonstrasikan informasi serta keterampilan berbahasa dengan baik. Mengacu pada hal tersebut, maka penelitian ini berjudul Keterbacaan Teks dalam Buku Siswa Kelas VI . 


\section{METODE PENELITIAN}

Penelitian ini menggunakan pendekatan kuantitatifkualitatif dengan metode deskriptif. Penelitian ini berbentuk kuantitatif karenakan memerikan tingkat keterbacaaan teks berdasarkan grafik Fry, sedangkan penelitian ini berjenis kualitatif karena akan memerikan keterbacaan berdasarkan profil teks dan disajikan hasil analisis dalam bentuk deskripsi. Dalam hal ini peneliti memfokuskan pendeskripsian pada analisis tingkat keterbacaan. Sebagaimana disebutkan dalam latar belakang dan tujuan penelitian.

Berdasarkan latar belakang masalah, ada beberapa tujuan dari penelitian ini. Secara umum, penelitian ini bertujuan mendeskripsikan keterbacaan teks dalam buku Teks kelas VI SD. Berdasarkan tujuan umum tersebut ada tiga tujuan khusus penelitian ini. Pertama, penelitian ini bertujuan mendeskripsikan keterbacaaan teks dalam buku Teks SD kelas VI berdasarkan pengetahuan awal pembaca tentang topik teks. Kedua, penelitian ini bertujuan mendeskripsikan keterbacaaan teks dalam buku Teks SD kelas VI berdasarkan panjang pendek kata. Ketiga, penelitian ini bertujuan mendeskripsikan keterbacaaan teks dalam buku Teks SD kelas VI berdasarkan aspek kontrol kosakata yang dipengaruhi oleh pengetahuan siswa kelas VI SD.

Sehingga penelitian ini menggunakan metode deskriptif. Penelitian deskriptif adalah suatu bentuk penelitian yang ditujukan untuk mendeskripsikan fenomena-fenomena yang ada, baik fenomena alamiah maupun fenomena buatan manusia. Fenomena itu bisa berupa bentuk, aktifitas, karakteristik, perubahan, hubungan, kesamaan, dan perbedaan antara fenomena yang satu dengan fenomena yang lainnya (Sukmadinata, 2005:72).

Pada penelitian ini ada pelbagai data dan sumber data yang menjadi acuan untuk menghasilkan pemerian secara kuantitatif-kualitatif tentang keterbacaan teks yang terbuat dalam buku siswa kelas VI. Data yang berupa jumlah skor dari hasil pengerjaan siswa adalah jumlah skor tiap teks, jumlah skor seluruh hasil teks. Data, yakni jumlah skor seluruh siswa, digunakan sebagai data acuan tingkat keterbacaan teks di dalam buku Teks kelas VI.

Untuk mennghasilkan total skor siswa pada tiap teks digunakan rumus sebagai berikut.

$$
\mathrm{PS}=\underline{\Sigma \mathrm{TS}}
$$

TSS

Keterangan:

PS = Persentase skor seluruh teks

ITS = Total skor benar siswa

TSS $=$ Total skor seluruhnya
Setelah itu, persentase skor dalam Tabel 1.1 untuk menentukan tingkat keterbacaan teks dalam buku siswa kelas VI.

Tabel 1.1

Tingkat Keterbacaan Berdasarkan Persentasi Skor (Tes Asosiasi Kata)

\begin{tabular}{ccl}
\hline No. & $\begin{array}{l}\text { Pers. } \\
\text { Skor }\end{array}$ & Tingkat Keterbacaan \\
1 & $75-100$ & Mudah (siswa dapat membaca sendiri) \\
2 & $43-74$ & $\begin{array}{l}\text { Sedang (siswa dapat membaca dengan } \\
\text { bantuan) }\end{array}$ \\
3 & $0-42$ & $\begin{array}{l}\text { Sulit (bacaan kurang sesuai dengan } \\
\text { siswa) }\end{array}$ \\
\hline \multicolumn{3}{c}{ (Diolah dari Zakulaak dan Samuels, 1988:133) }
\end{tabular}

Data Berupa Jumlah Suku Kata dan Kalimat (Grafik Fry). Data yang berupa jumlah suku kata harus dikonversi terlebih dahulu (dikalikan 0,6) karena grafik Fry sebenarnya untuk teks bahasa Inggris, sedangkan teks sampel penelitian ini berbahasa Indonesia. Selanjutnya, jumlah suku kata dan kalimat digunakan sebagai dasar penentu titik temu di grafik Fry.

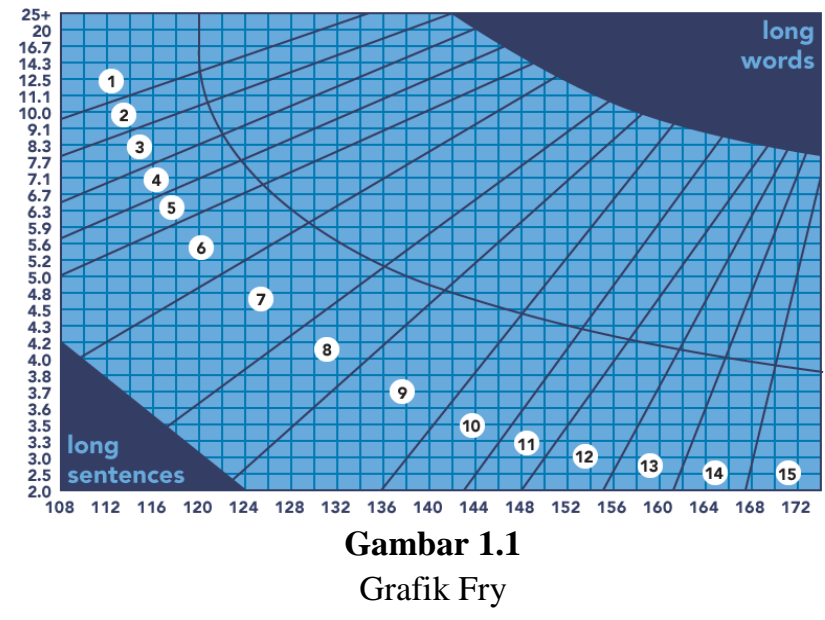

Keterangan gambar:

Angka di baris horizontal : rata-rata jumlah suku kata tiap seratus kata

Angka di baris vertikal : rata-rata jumlah kalimat tiap seratus kata

Angka 1 s.d. 15

: tingkat keterbacaan sesuai jenjang

Bagian terarsir hitam : tidak ada tingkat keterbacaan Hasil titik temu ditambah $(+1)$ dan dikurangi (-1). 
berikut.

Penggunaan grafik Fry dapat dicontohkan sebagai

$\begin{array}{ll}\text { Jumlah suku kata hasil konversi } & : 132 \\ \text { Jumlah Kalimat } & : 3,6 \\ \text { Titik Temu } & : 9\end{array}$

Oleh karena itu, teks tersebut sesuai dengan tingkat kelas 8, 9, dan 10. Data Berdasarkan Tes Cloze. Data yang dihasilkan dari tes tersebut yakni skor hasil pengerjaan siswa kelas VI. Analisis data tersebut sebagai berikut.

1) Isian siswa dikoreksi benar/salah dengan mencocokkan isian tersebut dengan kunci jawaban. Setelah itu, dihitung jumlah benar dan jumlah salah. Setelah penghitungan tersebut, jumlah benar dibagi jumlah kunci jawaban lalu dikali 100.

2) Skor tiap siswa tersebut dijumlahkan lalu dibagi jumlah siswa berdasarkan judul teks.

3) Skor yang dihasilkan di langkah ke-2 menjadi acuan tingkat keterbacaan berdasarkan tabel 1.2.

Tabel 1.2

Kriteria Tingkat Keterbacaan berdasarkan Hasil Tes Cloze

\begin{tabular}{lll}
\hline No. & $\begin{array}{l}\text { Pers. } \\
\text { Skor }\end{array}$ & Tingkat Keterbacaan \\
1 & $58-100$ & $\begin{array}{l}\text { Mudah (siswa dapat membaca } \\
\text { sendiri }\end{array}$ \\
2 & $44-57$ & $\begin{array}{l}\text { Sedaang (siswa dapat membaca } \\
\text { dengan bantuan) } \\
\text { Sulit (bacaan kurang sesuai dengan } \\
\text { siswa) }\end{array}$ \\
\hline
\end{tabular}

\section{HASIL PENELITIAN DAN PEMBAHASAN}

Proses belajar mengajar di sekolah merupakan salah satu contoh situasi resmi yang menuntut proses pembelajaran dengan baik dan benar. Sejalan dengan pernyataan tersebut, Arifin dan Hadi (2001:12) mengungkapkan bahwa bahasa Indonesia yang baik dan benar adalah penggunaan bahasa Indonesia yang digunakan sesuai dengan norma kemayarakatan dan sesuai kaidah bahasa Indonesia yang berlaku. Namun demikian, pada kenyataannya banyak terdapat buku yang sulit dimengerti oleh siswa. Sebagai contoh buku teks kels VI.

Baradja (1991: 128) menjelaskan banyak faktor yang bertanggung jawab akan adanya kesulitan dalam hal membaca teks. Baradja menyebutkan di antaranya perbedaaan latar belakang penulis dengan pembacaa, termasuk di dalamnya perbedaan pengetahuan, bahsa dan kode bahasa yang digunakan, kebudayaan, dan perbedaan asumsi.
Pernyataan Baradja sejalan dengan hasil penelitian ini. Pada teks topik tempat hidup tanaman teh hanya $28 \%$ siswa yang menjawab benar. Dilihat dari sudut pandang pengetahuan, siswa kelas VI sekolah sampel di SDN Paciran belum tahu banyak tentang tempat hidup tanaman teh. Secara geografis, wilayah Paciran Lamongan tidak sesuai dengan tanaman teh dan tidak terdapat tanaman teh. sehingga pengetahuan siswa minim. Tanaman teh yang biasa tumbuh di dataran tinggi cukup jauh dari daerah. Hal ini berpengaruh pada banyak-sedikit pengetahuan siswa tentang tenaman teh seperti yang terdapat pada teks.

Pada teks dengan topik bakau tumbuhan penjaga pesisir sebesar $24 \%$ siswa yang menjawab benar. Setelah diteliti, teks tersebut banyak menggunakan bahasa yang masih baru bagi siswa. Sebagai contoh kata polutan, stabil, dan terpaan yang namanya masih asing bagi sebagian besar siswa kelas VI di Paciran.

Pada teks dengan topik benda angkasa menghujam bumi di rusia tengah sebesar $37 \%$ siswa yang menjawab benar. Setelah diteliti, Pengetahuan tersebut merupakan gambaran tentang luar angkasa yang mereka dapatkan dari informasi media massa maupun media elektronik, bukan tentang Benda Angkasa Menghujam Bumi di Rusia Tengah seperti yang diceritakan dalam teks. Dikaitkan dengan pembelajaran, pembaca dengan mudah mengerti saat guru atau teman mereka menanyaakan hal tentang luar angkasa. Jadi sebaiknya memakai media pembelajaran seperti video, maupun layar lebar untuk mempermudah siswa memahami topik tersebut. Karena siswa masih dirasa kesulitan untuk membayangkan suatu materi tanpa media pendukung.

Short-term memory dan long-term memory dipengaruhi oleh jumlah suku kata yang harus diingat. Memori jangka-pendek cenderung menjaga konten kata demi kata, sedangkan memori jangka-panjang cenderung menjaga makna (Clark dan Clark, 1977:138). Dalam penelitian ini, jumlah rata-rata suku kata adalah 150,37 dari 7,38 kalimat sehingga tiap kalimat rata-rata 17,74 suku kata dengan level keterbacaan di level 7,8, dan 9. Oleh karena itu, siswa kelas VI berkecenderungan sulit mengingat 21,48 suku kata perkalimat dalam memori jangka-pendek.

Berdasarkan total skor tes Cloze seluruh tes adalah 317. skor tersebut menjadi data acuan tingkat keterbacaan teks dalam buku teks kelas VI dengan cara membagi skor tersebut dengan total skor sebenarnya, yakni 2.970. setelah itu, hasil pembagian skor seluruh tes dengan total skor sebenarnya adalah 0,10 . Hasil persentase tersebut adalah $10 \%$. Berdasarkan kesesuaian maka tingkat keterbacaan teks dalam buku teks kelas VI adalah sulit, yakni teks 
dalam buku tersebut sulit dibaca dan dipahami siswa yang bersekolah di SDN Paciran 1.

Peneliti merasa bahwa perlu adanya peningkatan kualitas buku yang sesuai dengan keterbacaan siswa. Hasil analisis teks berdasarkan pengetahuan awal pembaca tentang topik tertentu dalam penelitian ini memiliki tingkat keterbacaan yang rendah, yaitu sebesar $29 \%$. Kemudian hasil analisis menggunakan grafik Fry Jumlah Suku kata 150,37 dan Jumlah Kalimat 7,38, teks dalam buku tersebut sulit dibaca dan dipahami oleh siswa kelas VI karena titik pertemuan berada pada level 8 dan mendekati daerah long words. Dan Hasil persentase tes Cloze adalah 10\%. Teks dalam buku tersebut termasuk sulit dibaca dan dipahami siswa yang bersekolah di SDN Paciran 1. Semakin rendah tingkat keterbacaan suatu teks semakin sukar teks tersebut dipahami siswa.

\section{SIMPULAN}

Keterbacaan teks dalam buku siswa kelas VI berdasarkan tiga hal, yaitu berdasarkan Teks Asosiasi kata, Grafik Fry, dan Tes Cloze. Berdasarkan kesesuaian teks dengan pengetahuan awal pembaca, teks dalam buku siswa kelas VI kurang bisa dipahami oleh siswa kelas VI. Hal tersebut dibuktikan dengan hasil tes asosiasi kata, yaitu 29\%. Dengan demikian, teks dalam buku siswa kelas VI kurang bisa dipahami oleh siswa kelas VI.

Berdasarkan panjang-pendek kata yang disesuaikan dengan grafik Fry, titik temu antara jumlah suku kata dengan jumlah kalimat ada di level 8 serta mendekati daerah long words. Hal itu berarti teks dalam buku siswa kelas VI sesuai dengan kelas VII, kelas VIII, dan kelas IX. Dengan demikian, teks dalam buku siswa kelas VI kurang bisa dipahami oleh siswa kelas VI.

Berdasarkan hasil tes cloze pembagian skor seluruh tes dengan total skor sebenarnya adalah 0,10. Hasil persentase tersebut adalah $10 \%$. Berdasarkan kesesuaian maka tingkat keterbacaan teks dalam buku teks kelas VI adalah sulit, yakni teks dalam buku tersebut sulit dibaca dan dipahami siswa yang bersekolah di SDN Paciran 1 .

\section{DAFTAR PUSTAKA}

Arifin, Z. dan Hadi. F. (2001). 1001 Kesalahan Berbahasa. Jakarta: CV Akademika Presindo.

Fadillah, M. 2014. Implementasi Kurikulum 2013. Yogyakarta: Ar-Ruzz Media.

Gilliland, John. 1972. Readability. London: Holder and Stroughton
Ginting, Setia. 1990. Kajian tentang Metode Uji Keterbacaan sebagai Penentu Kefektifan Materi Bacaan. Tesis. IKIP Malang.

Harjasujana, A.S dan Yeti Mulyati. 1996. Membaca 2. Jakarta: Departemen Pendidikan dan Kebudayaan.

Muchlisoh. 1996. Pendidikan Bahasa Indonesia 3. Jakarta: Depdikbud

Pusat Perbukuan Nasional. 2003. Pedoman Pengembangan Standar Perbukuan. Jakarta: Departemen Pendidikan Nasional.

Sakri, A. 1994. Petunjuk bagi Pengarang, Penyunting, dan Korektor. Seri Pembinaan Bahasa Tulis. Bandung:ITB.

Sitepu. 2014. Penulisan Buku Teks Pelajaran. Bandung: PT. Remaja Rosdakarya Readability. Journalism Quarterly.

Tarigan, H.GG. 1986. Pengajaran Kosakata. Bandung: PT Angkasa.

Zakulak, Beverley L dan Samuels, S. Jay. 1988. Readability: "It Past, Present, and Future". Newark, Delaware: International Reading Association, Inc. 